Article

\title{
Caught between COVID-19, Coup and Conflict-What Future for Myanmar Higher Education Reforms?
}

\author{
Khaing Phyu Htut ${ }^{1}$ (D), Marie Lall $^{1}$ and Camille Kandiko Howson ${ }^{2, *(D)}$ \\ 1 Institute of Education, University College London, London WC1E 6BT, UK; htutkhaingphyu@gmail.com (K.P.H.); \\ m.lall@ucl.ac.uk (M.L.) \\ 2 Centre for Higher Education Research and Scholarship, Imperial College London, London SW7 2AZ, UK \\ * Correspondence: c.howson@imperial.ac.uk
}

Citation: Htut, K.P.; Lall, M.; Kandiko Howson, C. Caught between COVID-19, Coup and Conflict-What Future for Myanmar Higher Education Reforms? Educ. Sci. 2022, 12, 67. https://doi.org/ 10.3390/educsci12020067

Academic Editor: Han Reichgelt

Received: 29 October 2021

Accepted: 11 January 2022

Published: 19 January 2022

Publisher's Note: MDPI stays neutral with regard to jurisdictional claims in published maps and institutional affiliations.

Copyright: (C) 2022 by the authors. Licensee MDPI, Basel, Switzerland. This article is an open access article distributed under the terms and conditions of the Creative Commons Attribution (CC BY) license (https:// creativecommons.org/licenses/by/ $4.0 /)$.

\begin{abstract}
On 1 February 2021, Myanmar military dictators seized power from the elected government and halted the country's budding reform process. This article explores how Myanmar's higher education (HE) sector was affected by the coup and COVID-19 and how this has resulted in societal conflict. The article reviews first the history of military coups, then the education reforms in general and what was done in HE, before discussing the effects of COVID-19 and the coup on the sector. Voices from $\mathrm{HE}$ teaching staff show the tension in the role of $\mathrm{HE}$ as a vehicle for reform and promulgation of those in power. The article argues that the national vision propagated by Myanmar's HE sector is juxtaposed to that propagated by the Tatmadaw, both claiming to represent Myanmar's future. This research highlights the dual forces of the COVID-19 pandemic and military coup at a crucial time for HE reforms in a fragile, conflict-affected state, with the future of the reform goals of equity and equality of the sector at stake.
\end{abstract}

Keywords: Myanmar military coup; higher education (HE); education reform; unstable states

\section{Introduction}

Much of the literature on democratic citizenship engages with how ideals are embedded in higher education (HE) systems [1-3]. There are, of course, a variety of HE systems, all shaped by their national political, social and economic contexts, the institutions that comprise them and the students that experience them. In Myanmar, HE has been both at the heart of student protests for democracy [4] and at the same time the education institution most repressed by successive military regimes that see students, academics and the HE sector as a challenge to their definition of Myanmar nationalism based on a narrow interpretation of Burmanisation [5,6] that prefers a closed country immune to globalisation and possible "westernisation" brought in through recent reforms. This is exemplified by the slogan of amyo (only the Burman race), barthar (only the Burmese language) and tharthanar (only the Buddhist religion). This was $U$ Nu's slogan who took the role of prime minister after Aung San's death. Subsequent military regimes since 1962 have adopted the same ideology.

The post-2012 education reforms that opened HE to international engagement and funding led to real progress in less than a decade [7]. While HE was not fully inclusive, with ethnic students much less likely to be able to access and complete HE, the reforms allowed the HE sector to engage with issues of inclusion and democratic ideas [8]. In relation to Myanmar, "ethnic" refers to ethnicities other than the Bamar majority. Myanmar's budding HE reforms were cut short by both COVID-19 and the military coup in February 2021, leaving the country in general and the HE sector in particular in conflict.

This article explores how Myanmar's HE sector was affected by the coup and COVID19 , drawing on the limited literature, data and reporting available on Myanmar at this time of crisis. This documentary research is complimented with a small field study including 
interviews with academics and a review of secondary literature. Analysis of these sources is integrated, finding that Myanmar's HE sector is plagued by a national conflict between students and academics on one side and the military regime on the other over the future of the country. The article reviews first the history of military coups, then the education reforms in general and what was done in HE in particular, before discussing the effects of COVID-19 and the coup on the sector. The article argues that the national vision propagated by Myanmar's HE sector is juxtaposed to that propagated by the Tatmadaw, with both claiming to represent Myanmar's future. The Tatmadaw, which took power in a military coup, is the official name of the armed forces of Myanmar, representing the nation's military forces administered by the Ministry of Defence and composed of the Army, the Navy and the Air Force. This research highlights the dual forces of the COVID-19 pandemic and military coup at a crucial time for HE reforms in a fragile, conflict-affected state, with the future of the reform goals of equity and equality of the sector at stake.

\section{Policy Reform in Unstable States}

Education is seen as a basic service to be delivered in fragile states, yet "education is in many states intricately connected with-if not a root cause of — conflict and instability" [9] (p.183). Education is also a major policy interest in fragile states for the international aid community, as omission of education can add further instability to fragile states. In the absence of education, there are dangers of young people joining radical groups [10], but there are also examples of how education can fuel or exacerbate conflict, perpetuate ethnic conflicts and increase gender inequalities. The discourse has shifted from one of education for peace to education in conflict [11] with the emergence of a sub-field of Education in Emergencies uniting research on weak, fragile, conflict- and crisis-affected contexts. Links between education and conflict have been under-researched [12], with HE fleetingly discussed in the literature. Much of the research addresses "post-war" contexts, but little addresses HE in countries in the midst of conflict or after military coups.

International organisations such as the World Bank and the Organisation for Economic Co-operation and Development (OECD) are increasingly involved in policy making in unstable states [13]), positioning $\mathrm{HE}$ as a global commodity. Homogenous globalised academic systems do, however, overlook local contexts and the multiple approaches developing countries have to educational reforms [14,15]. Conflicts can lead to radical discontinuities in education policies in weak states [16]. Accounting for national identity and understanding ideological reconstruction is key in developing educational reforms $[17,18]$ For example, in Arab states, HE became an important means to garner political support from the upwardly mobile middle classes while also centralizing state power [19]. Research shows that such rapid expansion of $\mathrm{HE}$ raises questions of quality [20], with new university providers including private universities, virtual learning and decentralised campuses, all in line with neoliberal models [21,22].

In Myanmar, international aid organisations became involved in educational reform processes in 2012 as the country opened up to the wider world [7]. Engagement from the UK, Australia and Japan brought in policies around equity and inclusion but also neoliberal discourses around competition, funding and autonomy-following repeated patterns seen across the developing world of policy borrowing [23]. Although international agencies, organisations and consultants may bring strategies, frameworks and practices [24], national actors both interpret and create educational policies [25]. They can also resist drives of globalisation to prioritise the local context [26]. Drawing on examples from Africa, Silva and Oliveira [27] identified patterns of depoliticisation in transnational policy making, offering "facades" of precision, rationality and universality [28]. However, such efforts may only superficially account for the reality of the politics and the competing forces within fragile states. "In relation to fragility, education is at the same time cause, effect, problem and possible solution" [9] (p. 181).

Tierney [29] argued for thinking of HE as a public good in addressing the needs of failed states. As unstable countries pursue development reforms, HE has a key "transition" 
role in supporting change and innovation [30]. Recontextualisation can be understood as a process of colonisation and appropriation of one practice by another [31]. HE functions as an ideological framework [32] for reforms, positioning it at the forefront of the shift from the old to a potentially new regime. Policy implementation is a site in which reform policies interact in the existing social milieu, which "allows for diverse interpretations of agency and power and, in consequence, for complex patterns of compliance and resistance" [33] (p.37). Post-Soviet countries provide examples of the key role HE can have in developing unstable states $[34,35]$.

Russell and Quaynor [36] in their study comparing Liberia and Rwanda noted the "contextual values of development, security, freedom of speech, and civic action and the overall importance of citizenship education in a post-conflict context" (p.248), drawing on Osler and Starkey's three dimensions of citizenship education: a structural or political; a cultural or personal dimension; and skills for democratic participation and active engagement [37]. In fragile states, these dimensions are relevant for staff and students. There is research on the impact of conflict on students [38] but less focus on staff. Lopes Cardozo and Shah [39] found the role of teachers, as civil servants and community members, during a period of conflict, affected their ability to engage in peace building afterwards.

In Myanmar - a country divided between the majority Burman (Bamar) and around $30-40 \%$ ethnic group ethnic nationality communities, with conflict dating to the end of the Second World War-research has mostly focused on the effects of conflict on school education rather than HE. Burmanisation has been a process used by the military rulers to bring the country together under the language and culture of the Bamar majority. This policy drives schools to teach in Burmese, resulting in few ethnic nationals reaching $\mathrm{HE}$. A national, and internationally supported, drive to support the redevelopment of urban flagship universities, particularly Yangon University, was seen as a way to regain national pride and regional standing [18]. However, that agenda contrasts with local needs for HE across the ethnically diverse regions in the country.

\section{Military Coups in Myanmar}

In the 70 years since independence from Britain in 1948, there have been three military takeovers in Myanmar (Burma). Myanmar was officially known as Burma before 1988; in the country's protests of the socialist government, which was a military-led authoritarian government, in 1988, the military seized power and changed the country's name to Myanmar: 1962, 1988 and 2021. In 1962, HE students were among the most active to protest against the General Ne Win led military coup. The main protests took place on 7 and 8 July 1962, resulting in a crackdown and the demolition of the Rangoon University Student Union building. Echoes of this past can be heard in the 1988 coup and 2021 [40].

In 1988, the spark of the nationwide protests was initiated in one of Myanmar's Higher Education Institutions (HEIs), Yangon Technological University, resulting in the unseating of Ne Win. Between 1962 and 1988, Myanmar, then known as Burma, was ruled for 26 years by General Ne Win and his BSPP. There were huge protests against the BSPP due to 25 years of economic mismanagement. The Tatmadaw cracked down brutally on the protesters, many of whom were students [41]. To this day, the student leaders of the 1988 uprising are known as the "88 Generation" and have a special status in Myanmar. In the early 2000s, a seven-step road map was devised to move the country from an absolute military dictatorship to a more participatory system, which would still be controlled by the Tatmadaw [42]. The new government was led by former General Thein Sein, who, like Ne Win before him, took off his uniform to become a civilian leader [43]. In the 2015 election, the Thein Sein backed USDP (Union Solidarity and Development Party) lost to NLD. Unlike the first time when the NLD competed for power in 1990, Thein Sein transferred power to the NLD led by Aung San Suu Kyi. 


\section{Myanmar Education Reforms: 2010-2020}

Key to Myanmar's reform path was the education sector. President Thein Sein's developed a 10-point education plan that would form the basis of what was to come over his following 4 years in office. Unlike any of his predecessors, he saw a role both for local civil society and international development partners such as the World Bank and UN organisations in Myanmar's development [42]. In February 2012, a Conference on Development Policy Options with Special Reference to the Health and Education Sectors was organised by the government and development partners. As a result of this conference, the Comprehensive Education Sector Review (CESR) was launched in July 2012. The CESR's responsibilities encompassed all sectors of teaching and learning, from early childhood education to $\mathrm{HE}$, and involved a wide range of ministries and departments that had a stake in education [44]. The focus of the CESR was on reviewing the formal state education sector around the country in four stages. After the first phase of work (entitled "Rapid Assessment"), proposals under consideration for basic education included increasing basic education from 11 to 12 years and changing the teacher career structure- - two major structural changes that would mean all other areas within education would have to adapt. The CESR completed its Phase 1 review in early 2013, followed by CESR Phase 2 (entitled "In-Depth Analysis"), where more detailed work was conducted resulting in detailed reports for each of the education sectors [45]. CESR Phases 1 and 2 provided a much clearer understanding of the status of the education sector, including recent achievements and priorities for continued reforms and investments. Phase 3 focused on the costings covering fiscal years 2016 through 2020 of what would be required to make the changes across the sector, and this was later followed by Phase 4, the writing of the National Education Sector Plan.

The development partners welcomed the CESR and took the opportunity to engage in Myanmar's education sector-many for the first time. Development partner involvement in Myanmar education was not new; they had come together previously-pooling some of their funds for the UNICEF-managed Multi-Donor Education Fund. Much of that engagement was limited to schools, yet the CESR opened the possibility for engagement with the HE sector as well. In 2013, the Thein Sein government set up the Education Promotion Implementation Committee (EPIC) that focused on drafting the new National Education Law. The Law engendered large nationwide student protests. Rose Metro [41] argued that student protests are linked to the country's history as students have protested for decades not only on education issues but also on social and economic issues. After the new education law was made public, the students organised themselves under the banner of the "Action Committee for Democratic Education" (ACDE) and went back onto the streets. Some of their 11 demands were: the inclusion of representatives of teachers and students in the legislation process of education policies and laws, by-laws and other related laws; the right to freely establish and operate student and teacher unions and legal recognition for them; establishment of the National Education Commission and University Coordination Committee mentioned in the approved National Education Law; self-determination and self-management in the educational affairs of individual state/regions and schools. These focused on issues of governance and autonomy, in particular the freedom to establish student and teacher unions, as well as the inclusion of teachers and students in HE policy making. One key reason for protests was for more autonomy in the HE sector [46]. Metro [4] argued that the National Education Law makes it clear that the three governments-the SPDC (1988-2010), the Thein Sein USDP led government (2015-2015) and the NLD-led government (2015-onwards) - have had very similar conceptions of "democratic education" and wanted to centralise control of HE and HEIs, the promised autonomy being largely symbolic.

After the 2015 elections, the reforms were taken over by the newly elected NLD government. Education policy did not change much. The National Education Strategic Plan (NESP) of 2016, launched by the NLD government in February 2017, was based almost entirely on the previous government's draft National Education Sector Plan that in turn had 
come out of the CESR [7]. Reaching its halfway point in the summer of 2019, a mid-term review (MTR) was undertaken to allow for a re-prioritisation and some streamlining of programmes within the Ministry of Education and to help draft NESP 2. The MTR's final report explained that the reforms were complex and ambitious because they involved many large-scale activities occurring simultaneously. The MTR stipulated that the education reforms still had a long way to go [47]. NESP 2 (2021-2030) was drawn up on the back of the MTR towards the end of 2019 and early 2020. Despite the recommendations made in the MTR, there was little consultation with the affected stakeholders. Before NESP 2 drafts could be revised or finalised, first COVID-19 and then the coup in 2021 struck Myanmar. Many development partners left on relief flights, and programmes were put on hold.

\section{Higher Education (HE) and the Reforms}

The HE system in Myanmar is highly centralised. Its 174 universities are under the jurisdiction of eight ministries [48]. Each ministry is responsible for the HE institutions and their curriculum under it, leaving universities with hardly any autonomy. The hiring of staff is also coordinated by the government, and most staff are rotated every two to four years to universities around the country, making the setting up of research teams almost impossible. The centralised "command and control" system has resulted in strict hierarchies with many senior academics worried about making decisions that might be counter to the Ministry's wishes [49]. Universities, therefore, have not been able to develop their own research programmes. Private HEIs in Myanmar are not permitted to identify themselves as universities, even if they are degree-awarding [50].

As part of the reforms, all two-year government education colleges (ECs) that train teachers are being transformed into four-year education degree colleges (EDCs). These reforms have expanded the $\mathrm{HE}$ sector and interfaced it with the basic education subsector [51]. There are 25 ECs across Myanmar, with at least one in each state or region, providing pre-service teacher education to prepare student teachers to teach at primary and lower secondary school levels in government schools.

The main issues faced by the HE sector are the quality of what is taught and the teaching methods, as academic teaching staff are not research-active in an international sense, and courses need updating to meet international standards [52]. The teaching language is theoretically English; however, this is rarely the case because the academic staff (as well as students) do not necessarily speak English well enough. Quality of teaching and learning is poor with rote learning as the norm, outdated textbooks, lack of information technology infrastructure, high teacher-student ratios and salaries that are deemed "unattractive" [53]. The system is under-resourced and lacks specialised teaching spaces such as laboratories. Reforms started only recently to engage with issues of access, quality and the designing of independent curricula [54]. Despite these challenges, universities, their staff and students were ambitious in their desire for change. Myanmar's HE reforms were primarily driven by three broad aspirations: (1) meeting Association of South-East Asian Nations (ASEAN) regional benchmarks for $\mathrm{HE}$; (2) gaining a place in international league tables; and (3) the need for HE and research to support post-conflict national development [8].

The NESP [55] identified three strategies for HE reform to start the journey to meet the sector's aspiration: (1) to strengthen HE governance and management capacity; (2) to improve the quality and relevance of HE; and (3) to expand equitable access to HE. This new vision engaged for the first time with Myanmar's ethnic and linguistic diversity, in stark contrast to the Tatmadaw's propagated Burmanisation of the previous 40+ years. Whilst the NESP promised to allow universities to gradually become more autonomous, the biggest hurdle remained the centralised budget controlled by the government. The granting of autonomy was tested by the University of Yangon and the University of Mandalay in being allowed to select their students [18] and, as of 2020, being allowed to hire some of their own staff as well.

Given the challenges, the reforms within the HE sector were going quite well [56]. Despite the pandemic, the MOE went on to draft the NESP 2 where the vision of HE was set 
as: "By the end of NESP, students have equal opportunities to access and succeed in a worldclass HE system. HEIs produce well-prepared graduates for meaningful employment and contribute relevant research to help develop a knowledge-based economy and achieve the Sustainable Development Goals" (unpublished; np). The ambitious vision included eight priority areas: access and inclusion, modern curriculum, teaching and learning, aligned assessment, management and quality assurance, sustainable financing, internationalisation and partnerships and research and innovation. These priority areas were paired up with strategies, targets and end outcomes. These were imbued by the ideals of the moral aspects of democracy espoused by DASSK [57].

The reforms allowed universities to engage with issues of inclusion, propagating a new way forward for the country, rooted in Buddhist tradition, yet engaged with the global community. In a 2018 national HE Conference, a MoE representative's presentation on Equity in Myanmar's Higher Education: Opportunities and Challenges emphasised that equity was still a major priority of Myanmar's HE reform. In analysing the HE reforms, Kandiko Howson and Lall [8] concluded "There are possibilities for developing countries such as Myanmar to showcase models for excellence that build on traditional values, including inclusion, care for the environment and more sustainable ways of living" (p.120). The HE reforms were progressing steadily until early 2020 when Myanmar was hit by the global pandemic.

\section{Methodology}

\subsection{Context of the Research}

This paper draws on the political context of Myanmar and the reform efforts over the past decade to explore the impact of the COVID-19 pandemic, the 2021 military coup and on-going conflict on and within HE. Limited data and reporting are available within or out of Myanmar. Given the current situation in Myanmar, formal fieldwork could not take place. Utmost importance has to be attached to the safety of those speaking out in the very challenging context where the military is arresting thousands on the smallest suspicion of expression of unfavourable opinion on them, amending penal codes such as the 505(A) penal code. The SAC inserted a new provision, section 505A, that could be used to punish comments regarding the illegitimacy of the coup or the military government, among others to create new offenses and expand existing offenses to target those speaking critically of the coup and the military [58]. Many of those arrested have died during interrogation. However, it is important to include the voices of those most affected by both COVID-19 and the coup-academics and teacher educators.

The authors, therefore, decided to informally contact university teachers and teacher educators in Myanmar through existing professional networks to capture their experiences and inform wider analysis of the future of the educational reforms. Interviews followed institutional ethical guidelines and best practice, ensuring participant anonymity and confidentiality, although a full institutional review board approval from within or outside the state was not possible due to Myanmar's political context [59]. The respondents (university teachers and teacher educators) were civil servants and part of HEIs, but they were expelled from their institutions by the SAC due to their participation in Civil Disobedience Movement (CDM). CDM is a movement joined by government staff across the Ministries. They detest the military coup and crackdown of protestors, and thus they refuse to do their jobs as long as the military holds power. The CDM is strongest in the Ministry of Education joined mainly by academic staff from universities and schools. They had been on the run and in hiding for their safety. Although the respondents were not under normal and stable circumstances, the respondents fully consented to the interviews and the recording of their responses in the article. The consent was given by email and recorded by the authors. They were fully informed of the intention of interviews and agreed to the publishing of the article in open-access mode. The authors, and respondents, on balancing the ethical considerations, concluded that including the voices of those in the midst of conflict was more reasonable than to further silence them. 


\subsection{Participants}

The respondents were divided equally between two groups: university teachers from the higher education sector (HE) and teacher educators from teacher education sector (TE). The sample size was intentionally kept small to manage the potential risks that could be incurred both towards the author in Myanmar and to the respondents [60]. Each of the two groups had one male and two female respondents, reflecting the Myanmar teacher sector where the majority are women. The university teachers were from different universities, and the teacher educators were from different teacher education institutions (TEIs).

All of the participants have joined the CDM which is an important factor in the resistance to the coup. The CDM across government ministries was a huge national movement and a hard blow to the military. The military tried to force the CDM staff back to work using different threats: arrests, warnings, suspensions and dismissals. Thousands have remained committed to the CDM despite the sanctions. All the participants for this study continued to be part of the CDM and reflected on this in their responses.

\subsection{Data Collection and Analysis}

There was a brief in-person virtual meeting with all respondents to explain the research project and to request their participation. That first step was particularly crucial at the beginning of the data collection process to better understand the challenging situation the respondents were in before suggestion of contribution to the article. Only after ascertained by the respondents that they were comfortable talking about the impact of the military coup on HE reforms, the research project was mentioned. Then the best and most comfortable way of participation in the project for the respondents was considered. It was decided collaboratively that the best way to gather information on the effects of COVID-19 and coup on the HE and TE sectors was to frame questions that would be not only pertinent to the sector but also to what the respondents are going through in the current context. Five questions were subsequently drafted and shared with the respondents and finalised with their feedback on what they felt was most important and comfortable to talk about. The short questionnaire about the effects of COVID-19 and the coup on the HE sector, as well as views on the visions for the sector considering an uncertain future, was then distributed to all respondents in early October, and responses were gathered after a week:

1. How did COVID affect the Higher Education(HE)/Teacher Education (TE) sector?

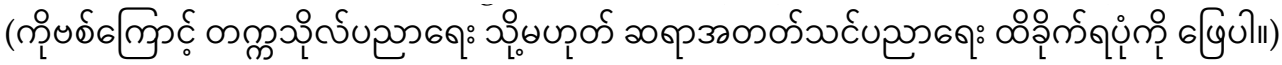
2.

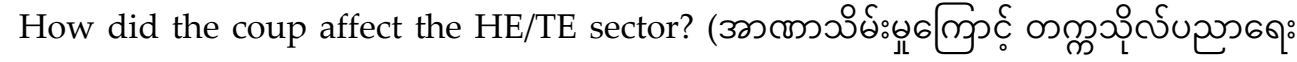

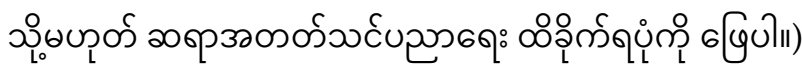

3. What should be the vision of the HE/TE sector for Myanmar's future?

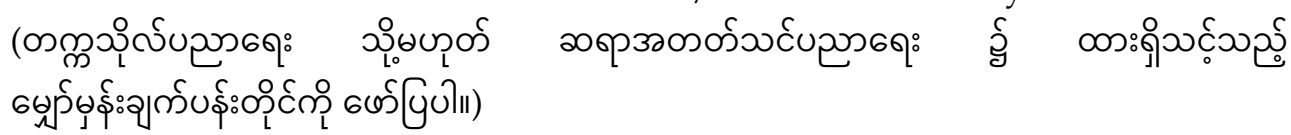

4. How does the ideal vision of the HE/TE sector contrast with what the Tatmadaw

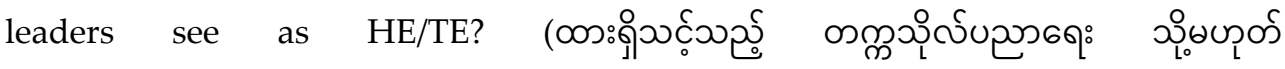

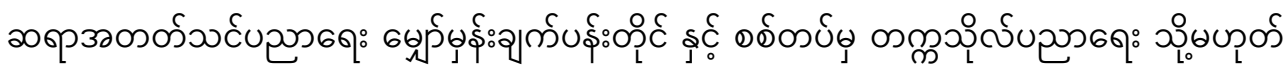

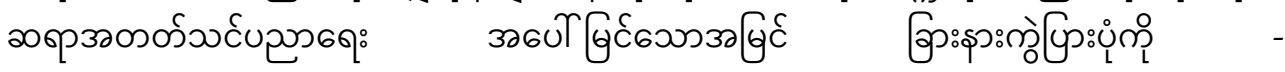

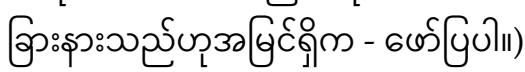

5. What future does CDMers have? How is it different from Non CDMers? (ฮิวิзวน์

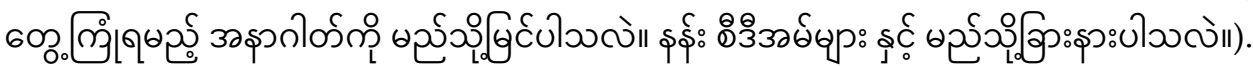


In the whole process, the first author was open to any questions and clarification requests from the respondents. It was also reiterated that participation was absolutely anonymous and voluntary, and they could back out anytime.

When they sent back their responses, the respondents emphasised that they found answering the questions really cathartic and beneficial. It gave them an opportunity to reflect on themselves and reinstate what they value most in their career: inclusive and quality education that is free from oppression. None of the respondents, despite their great losses (job, accommodation, income, future), expressed regret in joining the Civil Disobedience Movement (CDM). Each and every one of them was really proud of themselves for choosing what they felt was the right and ethical path, which is very important for their identity as Myanmar teachers and role models in life.

The sections below report on the thematic analysis of the data and allow voices from the anonymous HE and TE respondents to be heard, giving a real sense of how the HE sector in Myanmar was affected by both coup and COVID-19. The findings also draw on the limited policy documents, reporting and data that are currently available. They also show how the new conflict's battle lines have been drawn between HE and the Tatmadaw.

\section{Findings}

It is obvious from the findings that Myanmar HE teachers and academics are indeed caught between COVID-19, coup and conflict, and the future of HE is uncertain. It is also clear from the research that the reforms that had been made are being undone and that government-led, centralised HE will be impossible to grow either in numbers or quality in the next decade. These challenges are mainly brought about by three factors: COVID-19, coup and conflicts which are expounded in detail in the four sections below.

The first section "COVID-19" elaborates how Myanmar encountered COVID-19 and why the response in education was not adequate. The second section "Coup" explains how the challenges faced during COVID-19 were worsened by the coup highlighting the role of HE in opposition to dictatorship and injustices. That leads to the third section "Conflict" where conflict in ideologies, more than physical conflicts, between the Tatmadaw and the academics is laid out.

This research has implications for stakeholders to remedy the situation as best they can in coordinated efforts. Unless remedied, Myanmar is in danger of losing significant human capital which will affect the social and economic status of the country for decades. That, in turn, means a reform plan has to be taken up both in-country and with international partners. It is unfortunate that such dire need for coordination is deterred by the coup, dooming any reform plan.

\subsection{COVID-19}

Myanmar's first encounter with COVID-19 was more fortunate than that of many other countries. When the pandemic became widespread in Southeast Asia in March 2020, Myanmar schools were about to start their year-end 3-month holiday. Myanmar Universities were more affected as some universities were close to or amid their endof-semester exams. The Ministry of Education decided to close all institutions with the intention of holding exams after the pandemic. As one respondent reflected, this left students stranded:

Because of COVID, the exams in most universities were postponed. Students who were going to graduate cannot finish their studies. They [students] are distracted from their learning and in the middle of nowhere. (HE-PP)

When asked how COVID-19 further affected HE, respondents said that some institutions tried to offer online or hybrid learning but that in the end the third wave of COVID-19 (and the coup) defeated their efforts, and the quality of teaching and learning was badly affected. 
Initially, in the first wave, it brought positive effects, teachers inevitably learning new things to cope with modern digitalized education, like LMS [Learning Management Systems], virtual classrooms and so on. For the second and third wave + coup, there were more negative ones especially for students. Learning was almost shut down. (HE-YNSN)

COVID seriously affected the HE. No effective countermeasures to COVID have been taken for students not to disconnect their studies such as Online teaching, Hybrid teaching etc. Although some universities were reopened and had students attend the face-to-face classes for two weeks and let all-level of students pass exams, which really affect education quality. (HE-KTDM)

The pandemic also affected the newly integrated teacher education colleges. Myanmar's 25 teacher education colleges are being reformed to be degree-awarding bodies by extending 2-year certification courses to 4-year degree courses. Under the draft of NESP 2 , they were considered part of $\mathrm{HE}$, offering degrees like other universities. When the pandemic struck, the TE curriculum reform was completed only for the 1st year of the 4-year curriculum. Respondents working in teacher education had to move teaching online despite not having been prepared for such a situation. Respondents described the situation as follows:

The first is that the Ministry of Education has not properly trained teacher educators for online teaching, so it took longer than necessary to teach online. As a result, student teachers have lost their right to study. Another is that professional development programs for teacher educators are not as effective as face-to-face online switching. Lack of interest, Lack of participation (TE-TT)

The learning involved with the engagement of digital platforms was seen in some cases as a silver lining of the pandemic:

The pandemic affected Teacher Education seriously. Education Degree Colleges had to stop their regular system and the teaching-learning process had been totally ended for studentteachers. But that of teacher-educators could continue with online learning (British Council's Tree Process could proceed with online). In that situation, teacher-educators had to learn the use of the digital platform on learning not only for their professional development but for the preparation of giving online lectures to student-teachers. So, we can say that even the pandemic affected the Teacher Education sector negatively, it could change that issue to the opportunity of learning and using digital platforms for the Teacher-educators. (TE-MP)

Although one donor-led programme (TREE run by the British Council, funded by the British FCDO) was able to move online, the wider curricular reforms were stopped in their tracks, and the sector was marked by wider learning loss that will in the end affect the number of teachers in Myanmar schools.

Because of the COVID pandemic, to our Teacher Educator sector, we faced the failure of implementing incoming plans. We did not get a chance to keep reforming teacher education. We, teacher educators, lost opportunities to attend programs or projects for continuous professional development. For our student teachers, they also lost opportunities for continuously learning as we could not give and share with them teaching knowledge what they need to know. (TE-AM)

A COVID-19 Response and Recovery plan was developed, but it was not sufficiently comprehensive. The plan did not expect a long pandemic at first, and there were hopes that all education institutions including HEIs would resume as usual in June 2020. The failure to recognise the potential threat of the pandemic seems to be one of the causes of the lack of proactiveness from the MOE during the months of March, April and May 2020. The plan also seemed to lack coordination. Most of the discussions were quite centralised within the ministry, without taking stakeholder views into account. There were several different decision-making bodies with regard to the reopening of education institutions. The key body was the Central COVID-19 Committee led by the Ministry of Health and 
Sports that produced a 90-point checklist, which was used by the Ministry of Education to check education institutions for reopening. When the pandemic seemed to lapse in July, the Ministry of Education attempted first to open some high schools, but many schools found it challenging to meet the criteria on the checklist. The attempt to open schools failed with an increase in the number of local transmissions of COVID-19, and all schools were closed again from early August [61]. While the Ministry of Education made some effort for primary- and secondary-level students by setting up an Education TV channel [62] airing school lessons and distribution of recorded teacher training video lessons for teachers to attempt some learning continuity during the pandemic, nothing much was offered for university students and staff. The ministry established the Myanmar Digital Education Platform (MDEP) where the public could access textbooks and supplementary materials. Teacher training videos were also uploaded onto the MDEP with the intention of helping with the curriculum reform. However, the MDEP was not fully utilised as there was no facilitation to use it, no interactive engagement between teachers and students and no monitoring and tracking mechanisms of users. No materials were made available for universities or HE on the MDEP.

It was not clear why HEIs were not the first choice in reopening. It was also not clear why HEIs were not treated in the same way as schools by MOE when they develop the MDEP. MDEP prioritised schools and uploaded resources for basic education probably due to the diversity of courses in HEIs. The lack of decentralisation and autonomy of the HE sector also played a role as HEIs could have been allowed to arrange online learning themselves, but the hierarchical structure of the MOE did not make this possible [7]. In addition, in areas where the spread of COVID-19 was low such as Kayah, Chin and Kachin States, the nationwide closures applied without considering contextual differences. The end result was that all schools and HEIs across the country had to remain closed irrespective of infection numbers. Some ethnic schools and colleges in Kachin and Mon States run by Ethnic Armed Organisations remained open during this time, showing that a decentralised approach could have worked.

The COVID-19 crisis was worsened by the coup and the conflicts arising out of the coup as explained in the section below.

\subsection{Coup (The Third Coup d'état in 2021)}

On 1 February 2021, Myanmar experienced its third coup d'état, putting an end to a decade of economic and social reforms that were incomplete and still had a long way to go. The Tatmadaw seized power on the 1 of February from the NLD party that had just won the November 2020 elections by a landslide. The coup surprised most, as it was widely believed that even amid reforms, the Tatmadaw had retained its key role at the heart of government. General Min Aung Hlaing arrested the elected leader Aung San Suu Kyi, alleging electoral fraud. The Asian Network for Free Elections (ANFREL), one of two accredited foreign election observer missions, expressed its opinion that the results of the 2020 general elections were, by and large, representative of the will of the people of Myanmar [63]. According to Nikkei Asia's view [64], "the coup is a nakedly desperate attempt by this clique of almost-has-beens to turn back the tide after the democraticallyelected NLD government implemented an aggressively pro-market reform agenda that included mobilizing Western and East Asian investment into regular channels, improving public financial management and taking on corruption, which put the squeeze on the military's shadow empire." This resonates with the majority view of the over 50 million people. Philipp Annawitt who worked as an adviser to Myanmar's Parliaments added in his article: "the most important thing to understand about the coup leaders is that they are a clique of generals who control, through straw men, Myanmar's biggest corporations, as well as the lucrative trade in jade and other precious stones, narcotics and timber" [64], np. Their vision for the country is epitomised in a militarised view of Burmanisation, with the Tatmadaw as the country's largely Bamar elite controlling the rest of society. The opening 
of the country through the reforms had brought to the fore critical voices of this vision, not least across the HE sector, and this challenge had to be put down with force.

The international community reacted with horror and condemnation. Support for the reforms stopped as no more funds were to be transferred to the government now controlled by the Tatmadaw, renamed State Administration Council (SAC). Those in charge do not seem to have been too concerned; the SAC publicly announced that "We have to learn to walk with only a few friends" [65]. Few friends here mean China and Russia, who have a close relationship with the Myanmar military, but neither country has supported the wider education reforms.

\subsection{Higher Education's Reaction to the Coup}

Early in February, anti-coup protests started, led initially by doctors, nurses and students from government hospitals, which also included Myanmar's medical schools. University staff and students soon followed. The protests and resistance coalesced around different groups including Generation $\mathrm{Z}$ (those under 24 years old), the 88 Generation, the NLD (and the National Unity Government they had created) and the Civil Disobedience Movement (CDM) [66]. The education sector was mainly involved in the CDM where staff walked off the job and institutions had to shut [67]. Those who refused to return to work were suspended or dismissed [68]. The ministry itself also lost staff to the CDM, although a number of senior staff stayed in place, implicitly accepting the new order. The MOE issued a circular stating that promotions would be denied to those who had taken part in the CDM. Staff were asked to declare whether they supported the protests and to identify those who did [69]. Because HE staff are government employees, protesting academics were expelled from campus housing. In urban areas, the newly arrived Tatmadaw divisions that are usually stationed in ethnic conflict areas took over campuses as well as government hospitals to accommodate their soldiers. Teaching was suspended, mirroring the 1980s and 1990s when universities were closed for over a decade and a half and a whole generation of young people missed out on HE.

As in 1962 and 1988, in 2021, students were at the forefront of the revolt-although across the country many other groups joined the demonstrations, including academics and schoolteachers. Academic respondents described their reactions to the coup in the following terms:

First, it stopped all the progress the HE is having both in its management system and in its academic research. Second, students cannot have the continuous education via online programme that was being planned during the COVID before Coup. Third, many good teachers give up their spots as they no longer believe in the education system operated by the Military. (HE-PP)

The most important issue was the crumbling of the belief that the sector was moving in a new direction, away from the 50+ years of Tatmadaw dictatorship. The respondents confirmed that with the anti-coup protests, education and further progress were stopped in their tracks and that now there are many in hiding, making a "normal" functioning of universities impossible. When asked how they were affected respondents stated:

Disastrous! Over 90\% students and almost 40\% (initially almost 80\%) teachers and staffs joined CDM, boycotting the junta, saying bye to their universities as long as they are under the junta's control. Some teachers and students try to carry on education in all means possible but the majority cannot. (HE-YNSN)

Coup affected the HE seriously. Many staff have participated in CDM to protest it. As a result, some have been hidden themselves in places where they cannot be known, or some cannot go to international universities to pursue further studies, which has negatively effects not only for themselves but also on the HE. (HE-KTDM)

For TE, the responses were similar in that respondents pointed to the protesting staff and how this stopped teaching and learning. 
The coup affected the Teacher Education Sector negatively and seriously because those who are in the middle of the coup and who accepted it keep leading the teacher education sector. There would be no bright future because of those people who could not determine which is right or wrong and would like to encourage the bad people. (TE-AM)

Police reaction to the increasing crowds escalated from water cannons to sound grenades and rubber bullets. With the arrival of the light infantry divisions, the nature of the protests changed as soldiers fired live bullets on unarmed crowds and snipers took out individuals with shots to the head. The first killed was 20-year old Mya Thwate Thwate Khaing who participated in a mass protest on 9 February 2021 in Myanmar's capital, Naypyitaw [70]. Her death was followed by more than a thousand more, 1146 by 30 September [71] including 75 children [72].

The SAC, governed by the Chief of Staff General Min Aung Hlaing, increased the repression against the protesters. There have been reports of torture, and families are sometimes called to retrieve the bodies of those taken away the previous night. Student leaders went into hiding, and some young people fled to border areas where they have received combat training from Ethnic Armed Organisations. However, the Tatmadaw has escalated the conflict in ethnic areas as well-including the first aerial bombings in Karen and Kachin States in two decades. Mobile and wireless internet have been cut to make communication between protesters harder and all non-government media has been officially shut down as journalists are risking their lives to report. At the time of writing, street protests have largely ceased, but the conflict has been escalating with increasing numbers of young people across the country joining civil defence movements called People's Defence Force. It is unclear what the future holds; trust has been broken:

Because of the Coup, CDM has developed. Many teachers and students participated in $C D M$ and were involved in the revolution. So formal learning opportunities for studentteacher had been destroyed by the coup and teacher educators lost their jobs. Before the coup, we were going to implement the four-year new curriculum and upgrading Education Colleges to Education Degree Colleges, and all our plans have been destroyed by the coup. (TE-MP)

The main reason is that student teachers are losing their right to study. Some have given their lives in opposition to the dictator. Some have committed suicide due to mental illness. CDM teacher educators have been wrongfully arrested by the dictatorial military council. There were also killings. The trust between the teacher and the student; Respect and value. Understandings were ruined by a group of dictators. (TE-TT)

At the heart of the chasm between the Tatmadaw and the academics lie the different visions of how Myanmar should be governed, as discussed below.

\subsection{Conflict: Clash of Ideologies}

This is not the first time that the Tatmadaw has cracked down on protests (1962, 1988, 1990 and 2007). Opposition to coups has always had strong roots in HE despite the Tatmadaw's persistent attempts at indoctrination in both schools and universities [4]. From post-colonial days, HEIs, students and teachers have stood firm against all military coups in Myanmar. The student and teacher activism against injustice can be discerned in HE since the colonial days of 1920 when students from HE protested against the British colonial education system which was seen then as elitist [73].

Students and the wider HE sector have always suffered most with years of closure and academic repression; after the 1988 coup, schools and universities were closed three times-in Yangon, this was for 10 out of 12 years. The students joined back from where they had left off without any assessment on what their level was upon re-entry. The lost years were made up later by shortening the 4-year degrees to 3 years at universities. After the re-opening of universities and colleges in 1999, the government scattered universities in different regions. The university term was shortened by one year, providing a bachelor's degree for just a three-year course. In the eyes of the military, HE is not a necessary 
element of wider reforms. The education system should, in the view of the Tatmadaw, teach young people to respect the military and its position. Those who disrespect them are in revolt against the stalwarts of the nation. This understanding of the nation is rooted in Myanmar's nationalism that is linked to Burmanisation. This primacy of one ethnicity (Bamar) over other ethnic groups became a tactic the Tatmadaw used to attempt to legitimise itself through education. Cheesman [74] (p.iii) found that according to the school textbooks' normative model, the ideal citizen had distinct ethnic (Bamar), religious (Buddhist) and gender (male) characteristics and worked to benefit the state. "Part of the aim of the textbooks was to instil an understanding of "the Union" that conflates the state, nation, territory and people" [74] (p.1). Metro [75] (p.56) showed that what she calls a "trinity of activities-national unification, economic development, and religious patronage" are carried out by the military regime, reflecting ancient Myanmar kings who are "hero-ised" in the textbooks. At universities, Bumanisation has been evident by the lack of inclusion of ethnic students, acknowledged by the MOE official at the second Myanmar HE conference in 2018 [7].

Key to the understanding of Myanmar nationalism and a Myanmar identity pushed by the Tatmadaw is the unity of the nation. Throughout its control of Myanmar since 1962, the Tatmadaw has portrayed itself as the saviour of the nation, the defender of the Buddhist religion and guardian from Westernisation. The 1962 coup leader Ne Win, who inaugurated the history of military dictatorships, clung to the values of nationalism and social redemption based on anti-colonialism against the English and Japanese. The idea of the army as the backbone of the country was born in those years: its men belong to the Bamar ethnic group — the predominant one in Myanmar-they are Buddhists and consider themselves the guardians of the homeland [76]. Its definition of nationalism is prevalent in its infamous propaganda lines visible on the signboards across Myanmar in Figure 1: "Tatmadaw is the father, Tatmadaw is the mother," "Oppose those relying on external elements, acting as stooges, holding negative views", "Oppose foreign nations, interfering in internal affairs of the state."

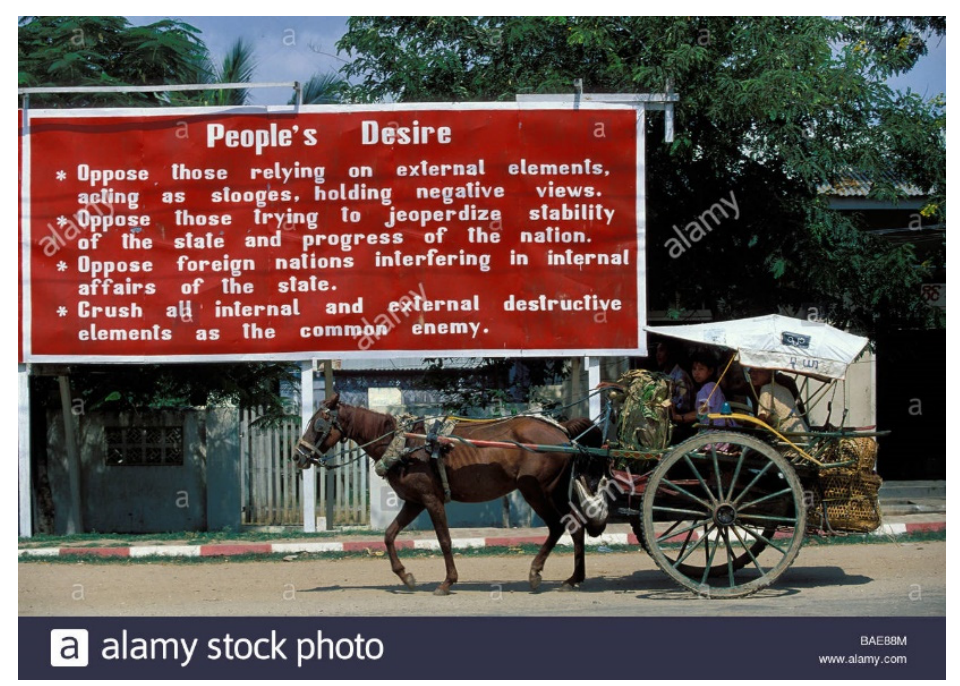

Figure 1. One of the signboards set up across Myanmar by the military government until 2011.

The Associations and parties, such as the USDA (Union Solidarity and Development Association) and USDP (Union Solidarity and Development Party), born out of the military, hold similar outdated ideologies unacceptable to many. The military and their view of nationalism narrowly defining the Tatmadaw as the supreme to be trusted, revered without questions, are obvious through those lines in the picture that have zero outward look in the modern days and are increasingly challenged by teachers and students in HE. Academic respondents described the Tatmadaw's priorities as follows:

Tatmadaw does not really have any good-will on the development of Myanmar's education. For them, it appears people should be lacking thinking skills so that they can control 
people and exploit country's resources for their own sake. They might be thinking that the lower the education level, the better for them to take advantage of it. (HE-KTDM)

HE was seen as a particular threat to the country as it promoted different and critical views that would be hard to control.

The junta sees academic freedom, autonomy and international collaboration as their threats. Teachers are just staff to promote a stratocracy state (which they think would be peaceful and developed and in reality not. My ideal vision is the opposite. (HE-YNSN)

This was reflected by TE staff who pointed to how education was not allowed to foster an outlook that would allow for growth, change and development.

We see education as a kind of political affair in a country. A teacher should have a sound knowledge and interest in the political situation of his or her country and wants to participate in its movement. But, the military junta see education separately, not related to the political crisis. We could say it is a kind of being provincial in outlook. (TE-MP)

One TE respondent accused the Tatmadaw of not allowing the sector to develop on purpose.

Although we focus on teacher education to create updated themes for improving and reforming a better teacher education system, the Tatmadaw leaders see as Teacher Education sector that it is not as important as what they do to get authority on Myanmar people. To my mind, the junta has been creating the teacher education system outdated as we have postponed all our upcoming education plans. (TE-AM)

The issue of critical thinking and closed mindset was also mentioned by both teacher educators and academics:

I find that the HE of Myanmar is quite reluctant to collaborate and cooperate with other organizations. The hierarchy system of the organization doesn't allow people, teaching staffs and administrative staffs, to have autonomy and will to develop themselves. The closed structure of the system make people work in the government since the beginning of their working life till they get pension. (HE-PP)

Teacher education is about thinking, thinking, thinking. Values It is to cultivate teachers who are constantly learning based on skills. The military's view is that teachers are more likely to give birth to children who will say "yes" than "think" rather than think. Teacher education is seen as the best place to brainwash the people. (TE-TT)

This is reflected in the old textbooks that were used pre-reform in Myanmar schools and that show the Tatmadaw's supremacy through the glorification of Myanmar's ancient kings [75].

The contrast with views from the HE sector could not be greater. When asked what vision should govern Myanmar, respondents spoke about increased quality, including an updated curriculum and students getting jobs at the end of their studies.

The vision of the HE should be promoting quality of teachers from all levels to produce quality human resources for different sectors by providing Continuous Professional Development activities to teachers, by reviewing the curriculum and updating it accordingly to the fast flowing changes of today's era. (HE-KTDM)

My expected vision of the future HE is to build up an active and innovative society for the teachers and students which advocates the transparent working system. I hope students who finished their degrees can have the appropriate job opportunities and they can have opportunities to equip themselves with the required skills. (HE-PP)

Reform visions from teacher educators were similar. After many years of substandard support, both academics and teacher educators want to see a focus on capacity development so they can help their students and wider society grow. 
In my opinion, based on the current political crisis, the vision of the Teacher Education sector should include those facts such as to produce educated teachers with high knowledge of Myanmar Political situation and the role of education in a political affair, federal education system, and respect to equity and inclusion. (to produce educated teachers who can perform the federal education system successfully). (TE-MP)

The vision of the Teacher Education Sector of Myanmar's future should be with a variety of updated, inclusive, and modernized themes to implement the federal education system because we must lead our sector to be with international standards. To systematically reform our sector, there must be included 21st-century skills and therefore, qualified teachers would be well-produced and it would become an inclusive and comprehensive teacher educator system. (TE-AM)

One HE teacher also mentioned inclusion, reminding us that an updated curriculum and more capacity building will not be enough to create a new, inclusive Myanmar nation.

1. Tear down the decaying systems of hidden academic frauds and deep rooted bureaucracy. (Eliminate all corruptions in it)

2. Build a Higher Education System of REAL autonomy, academic freedom + quality assurance.

3. Adapt in accordance with the needs of a Federal nation, not a single race state. (HE-YNSN)

This echoes Mullen's [77] pathways to democratic change: contentious politics, everyday resistance and reconstructive politics [78]. The unanswered questions for many are how this will ever be possible given the conflict between HE and the Tatmadaw.

\section{Discussion: Caught between COVID-19, Coup and Conflict}

The closures of education institutions due to COVID-19 have resulted in at least a oneyear learning gap at both school and university levels. They were closed from March 2020 due to the spread of COVID-19-except for a brief opening in the summer. Myanmar's 164 HEIs remained closed at the time of writing of this article. The coup jeopardised education plans and the continuation of reforms that had already suffered greatly due to the pandemic. The coup prolonged the closures, made school premises unsafe, politicised education and pushed teachers and academics out of their professions. According to Reuters [79], an official from the Myanmar Teacher's Federation (MTF) reported 19,500 HE staff and 125,900 basic education teachers were suspended from their duties after going on strike and joining the CDM (estimated to be 55 per cent and 31 per cent of all staff, respectively). The coup raises ethical questions for staff, such as teacher educators, about returning to work, including their security, the role of education in supporting the coup and future prospects for teachers [80].

Despite the shortage of staff, the military re-opened universities, colleges and institutes for doctoral courses, master's studies (written test) and final-year undergraduate students the first week of May 2021. Only a handful of students attended, according to witnesses and student union sources across the country [81]. Then, the military re-opened schools on 1 June, but the MTF [82] said more than 90 per cent of students did not turn up to attend classes as many families chose to keep their children at home [83]. All HE institutions and schools were closed again in August 2021 due to the severe third wave of COVID-19. With or without the pandemic, it is obvious that the HE institutions in Myanmar are barely functioning. With the challenges of COVID-19 and the limited capacity of the Ministry of Education, exacerbated by the chaos created by the military coup, Myanmar's education is in an extremely difficult state.

Now that education in Myanmar faces a triple crisis: COVID-19, coup and conflict, prospects are grim. The present triple crisis in education is expected by most observers to persist for several years. There are five principal reasons for this. First, recent progress on highly complex and ambitious reforms to improve quality in the formal education system 
has stalled and will likely reverse due to ongoing poor decision making by the SAC, the lack of credibility of SAC-run education for most of the population and the withdrawal of financial and technical support by development partners. Second, the COVID-19 pandemic is unlikely to abate in Myanmar as the SAC-led government is unlikely to be able to manage effective and trusted testing, vaccination and treatment. This might mean prolonged institutional closures until the pandemic is controlled. Third, the SAC has suspended and may terminate the contracts of more than $25 \%$ of the teaching and academic workforce (well over 125,000 people) as a result of their participation in the Civil Disobedience Movement. This shortage of staff will mean that many students will not receive the kind of education envisioned by the NESP and the reforms. Fourth, the circumstances in which most academics and students across the country return voluntarily to SAC-controlled HEIs seem unrealistic - in fact, students are involved in the PDFs, continuing to fight the regime. This leads to the final point of conflict and potential civil war that is likely to be ongoing for the foreseeable future. Despite the ASEAN summit that called for an end to violence, no one can be sure when or how the standoff is going to end. What is clear is that the HE sector will again take a long time to recover.

\section{Conclusions}

In conclusion, we are seeing a national conflict between students and academics on one side and the Tatmadaw / military regime on the other over the future of the country. The conflict has grounds in the ideologies held by the xenophobic Tatmadaw which seems determined on putting the country back into the days of fear, separation and oppression of HE, working against HE reforms that seek to base the country's future on knowledge, freedom and fairness to all. Interestingly, the Tatmadaw seems to believe that the old ways would still work-such as propagating Buddhism and monks and relentlessly portraying the Tatmadaw as the saviour of the nation from harm and disintegration. While these strategies might have taken root in days of darkness, the public-especially students and academics - now have a far better understanding of what Myanmar could look like. The brutal crackdown by the Tatmadaw has awoken sympathies with the pain and injustice experienced by minorities in the name of protecting the country. The conflict has divided the nation into two key groups. The broad public want the Tatmadaw to disappear from the political scene forever. However, the Tatmadaw and their supporters are using arms to maintain their power over the country. Myanmar is becoming more and more divided and polarised. Any future international engagement and continuation of the educational reforms will need to engage with these competing views of the future of the country.

There is also a new conflict within HE. In HE, the coup has caused what seems today an unbridgeable divide between the CDM and non-CDM participants as evidenced by the view below:

CDMers hope to become a democratic nation and have a federal education system. They love the truth and want to leave the military government. They have no wish to stay long with fear under the junta. They want to get freedom from fear and hope to create a better teacher education system with qualified and democratic leaders. Alternatively, non-CDMers are different from CDMers because those who keep working under the military government want to stay their lives with ease and comfort. They do not have the sense to differentiate what is right or wrong. (TE-AM)

There might be students and academics who are non-CDM due to reasons other than supporting the SAC. However, for many years, universities and HE will have to bear the burden of seeing the two groups as white and black, with no other shades in between. The view expressed here sadly summarised the potential struggles of Myanmar HE:

Ironically, neither will have real universities to ethically work in, under the junta. CDMers still have students but no secure places to conduct classes. Non-CDMers still get salaries but almost no students accepting them. As long as students can respect 
them as moral teachers, teachers can be teachers, which will be difficult for Non-CDMers. (HE-YNSN)

This research aimed to capture views of those caught between COVID-19, the coup and on-going conflict in a sensitive way, allowing their voices to be heard and their safety to be maintained [84]. It adds to the literature on universities as sites of civil disobedience and unrest in fragile states $[85,86]$. While most research focuses on rebuilding post-war states, here we show the tensions that arise for HE in the midst of conflict. Drawing on the work of Lopes Cardozo and Shah [39], this research raises questions about the future role of HE staff-CDM and non-CDM-in (potential) rebuilding efforts in the future. Finally, this paper aims to highlight the tensions between the HE sector and the Tatmadaw, aiming to inform future policy work by those within and beyond the national borders.

The article concludes that the national vision propagated by Myanmar's HE sector is juxtaposed to that propagated by the Tatmadaw, both claiming to represent Myanmar's future. What does the future hold? There might still be a glimpse of hope if the right support is made available as shown in the view below:

CDM teachers can be emotionally and physically insecure. The safety of their family members can also be compromised. They may also lose the right to further education locally. However, with the help of international organizations, CDM students might be able to continue their education. CDM teachers will definitely gain the respect and trust of the people which Non-CDMers can never hope to get again. It is true that some CDM teachers will have to give up their beloved teaching profession to make a living but there will also be others who might still get a job in their same profession. These CDM teachers will lead the way for future federal education and rehabilitation. Some CDMs might not be working as teachers anymore but they will still be very important in carrying out national reconstruction efforts in collaboration with local and foreign organizations. (TE-TT)

Author Contributions: Conceptualization, K.P.H. and M.L.; Formal analysis, K.P.H.; Methodology, M.L.; Writing-original draft, K.P.H., M.L. and C.K.H.; Writing-review \& editing, K.P.H., M.L. and C.K.H. All authors have read and agreed to the published version of the manuscript.

Funding: This research received no external funding.

Institutional Review Board Statement: Not Applicable.

Informed Consent Statement: Informed consent was obtained from all subjects involved in the study.

Data Availability Statement: The data presented in this study are available on request from the corresponding author. The data are not publicly available due to the safety and security of the respondents.

Conflicts of Interest: The authors declare no conflict of interest.

\section{References}

1. Chiroma, J.A. Democratic Citizenship Education and Its Implications for Kenyan Higher Education. Ph.D. Thesis, Stellenbosch University, Stellenbosch, South Africa, 2015.

2. Crick, B.; Lockyer, A. Education for Democratic Citizenship: Issues of Theory and Practice; Routledge: London, UK, 2017.

3. Luescher-Mamashela, T.M. The University in Africa and Democratic Citizenship; Center for Higher Education Transformation: Wynberg, South Africa, 2011.

4. Metro, R. Students and teachers as agents of democratization and national reconciliation in Burma: Realities and possibilities. In Metamorphosis: Studies in Social and Political Change in Myanmar; Nus Press: Singapore, 2011; pp. 209-233.

5. Houtman, G. Mental Culture in Burmese Crisis Politics: Aung San Suu Kyi and the National League for Democracy; Institute for the Study of Languages and Cultures of Asia and Africa: Tokyo, Japan, 1999.

6. Myint-U, T. The Making of Modern Burma; Cambridge University Press: New York, NY, USA, 2001.

7. Lall, M. Myanmar's Education Reforms-A Pathway to Social Justice? UCL Press: London, UK, 2021.

8. Kandiko Howson, C.; Lall, M. Higher Education reform in Myanmar: Neoliberalism versus an inclusive developmental agenda. Glob. Soc. Educ. 2020, 18, 109-124. [CrossRef]

9. Kirk, J. Education and fragile states. Glob. Soc. Educ. 2007, 5, 181-200. [CrossRef] 
10. US Agency for International Development (USAID). Youth and Conflict; USAID Office of Conflict Management and Mitigation: Washington, DC, USA, 2005.

11. Lerch, J.C.; Buckner, E. From education for peace to education in conflict: Changes in UNESCO discourse, 1945-2015. Glob. Soc. Educ. 2018, 16, 27-48. [CrossRef]

12. Davies, L. Education and Conflict: Complexity and Chaos; Routledge: London, UK, 2004.

13. Baćević, J. From Class to Identity: The Politics of Education Reforms in Former Yugoslavia; Central European University Press: Budapest, Hungary, 2014.

14. Kempner, K.; Jurema, A.L. The Global Politics of Education: Brazil and the World Bank. High. Educ. 2002, 43, 331-354. [CrossRef]

15. Naidoo, R. Higher education as a global commodity: The perils and promises for developing countries. Obs. Bord. High. Educ. 2007, 14, 1-19.

16. Balarin, M. Promoting educational reforms in weak states: The case of radical policy discontinuity in Peru. Glob. Soc. Educ. 2008, 6, 163-178. [CrossRef]

17. Couch, D. The policy reassembly of Afghanistan's higher education system. Glob. Soc. Educ. 2019, 17, 44-60. [CrossRef]

18. Esson, J.; Wang, K. Reforming a university during political transformation: A case study of Yangon University in Myanmar. Stud. High. Educ. 2018, 43, 1184-1195. [CrossRef]

19. Mazawi, A.E. Contrasting Perspectives on Higher Education in the Arab States. In Higher Education: Handbook of Theory and Research; Smart, J., Ed.; Springer: London, UK, 2005; pp. 133-189.

20. Kwiek, M. The two decades of privatization in Polish higher education: Cost-sharing, equity, and access. Die Hochsch. 2008, 2, 94-112.

21. Abdesallem, T. Financing Higher Education in Tunisia; Economic Research Forum: Cairo, Egypt, 2009.

22. Buckner, E.; Khuloud, S. Syria's Next Generation: Youth Unemployment, Education, and Exclusion. Educ. Bus. Soc. Contemp. Middle East. 2010, 3, 86-98. [CrossRef]

23. Steiner-Khamsi, G. New directions in policy borrowing research. Asia Pac. Educ. Rev. 2016, 17, 381-390. [CrossRef]

24. Verger, A.; Clara, F.; Adrián, Z. The Privatization of Education: A Political Economy of Global Education Reform; Teachers College Press: New York, NY, USA, 2016.

25. George, J.; Theodore, L. Exploring the Global/Local Boundary in Education in Developing Countries: The Case of the Caribbean. Comp. A J. Comp. Int. Educ. 2011, 41, 721-734. [CrossRef]

26. Verger, A.; Steiner-Khamsi, G.; Lubienski, C. The Emerging Global Education Industry: Analysing Market-Making in Education through Market Sociology. Glob. Soc. Educ. 2017, 15, 325-340. [CrossRef]

27. Silva, R.D.; Oliveira, J. Global education policy in African fragile and conflict-affected states: Examining the Global Partnership for Education. Glob. Soc. Educ. 2021, 1-15. [CrossRef]

28. Steiner-Khamsi, G. What is Wrong with the 'What-Went-Right' Approach in Educational Policy? Eur. Educ. Res. J. 2013, 12, 20-33. [CrossRef]

29. Tierney, W.G. The role of tertiary education in fixing failed states: Globalization and public goods. J. Peace Educ. 2011, 8, 127-142. [CrossRef]

30. Mitter, W. Transformation Research and Comparative Educational Studies. In After Communism and Apartheid, Transformation of Education in Germany and South Africa; Reuter, L.R., Döbert, H., Eds.; Peter Lang: Frankfurt Am Main, Germany, 2002 ; pp. 197-205.

31. Chouliaraki, L.; Fairclough, N. Discourse in Late Modernity; EUP: Edinburgh, UK, 1999.

32. Althusser, L. On Ideology; Verso: London, UK, 2008.

33. Szkudlarek, T.; Stankiewicz, Ł. Future perfect? Conflict and agency in higher education reform in Poland. Int. J. Acad. Dev. 2014, 19,37-49. [CrossRef]

34. Gounko, T.; Smale, W. Modernization of Russian higher education: Exploring paths of influence. Comp. A J. Comp. Int. Educ. 2007, 37, 533-548. [CrossRef]

35. Milton, S.; Barakat, S. Higher Education as the Catalyst of Recovery in Conflict-Affected Societies. Glob. Soc. Educ. 2016, 14, 403-421. [CrossRef]

36. Russell, S.G.; Quaynor, L. Constructing citizenship in post-conflict contexts: The cases of Liberia and Rwanda. Glob. Soc. Educ. 2017, 15, 248-270. [CrossRef]

37. Osler, A.; Starkey, H. Changing Citizenship: Democracy and Inclusion in Education; Open University Press: Maidenhead, UK, 2005.

38. Ben-Tsur, D. Academic studies amid violent conflict: A study of the impact of ongoing conflict on a student population. Glob. Soc. Educ. 2009, 7, 457-472. [CrossRef]

39. Lopes Cardozo, M.T.; Shah, R. 'The fruit caught between two stones': The conflicted position of teachers within Aceh's independence struggle. Glob. Soc. Educ. 2016, 14, 331-344. [CrossRef]

40. Ray, E.; Giannini, T. Beyond the Coup in Myanmar: Echoes of the Past, Crises of the Moment, Visions of the Future; Just Security and the International Human Rights Clinic at Harvard Law School: Cambridge, MA, USA, 2021. Available online: https: / / www.justsecurity. org/75826/beyond-the-coup-in-myanmar-echoes-of-the-past-crises-of-the-moment-visions-of-the-future/ (accessed on $10 \mathrm{Au}-$ gust 2021).

41. Metro, R. Whose Democracy? The University Student Protests in Burma/Myanmar, 2014-2016. In Universities and Conflict; Millican, J., Ed.; Routledge: London, UK, 2017; pp. 205-218. Available online: https://www.taylorfrancis.com/chapters/edit/10 4324/9781315107578-15/whose-democracy-rosalie-metro (accessed on 28 October 2021). 
42. Lall, M. Understanding Reform in Myanmar; Hurst: London, UK, 2016.

43. Burma Campaign, U.K. About Burma. 2021. Available online: https://burmacampaign.org.uk/about-burma/ (accessed on 15 August 2021).

44. CESR. Comprehensive Education Sector Review: Technical Annex on the Higher Education Subsector, Phase 1; Government of Myanmar: Nay Pyi Taw, Myanmar, 2013. Available online: http://themimu.info/sites/themimu.info/files/documents/Report_CESR_ Phase_1_Technical_Annex_on_the_Higher_Education_Subsector_Mar2013.pdf (accessed on 5 August 2021).

45. CESR. Comprehensive Education Sector Review: Technical Annex of the Higher Education Subsector: Phase 2; Government of Myanmar: Nay Pyi Taw, Myanmar, 2014.

46. Lopes Cardozo, M.T.A.; Maber, E.J.T. (Eds.) Sustainable Peacebuilding and Social Justice in Times of Transition: Findings on the Role of Education in Myanmar; Springer: Berlin/Heidelberg, Germany, 2019.

47. Mid Term Review. Government of Myanmar. Mid Term Review NESP 2016-2021; Ministry of Education: Nay Pyi Taw, Myanmar, 2020.

48. Ministry of Education. Presentation by Dr Aung Khin Myint. Available online: http:/ / moe.gov.mm (accessed on 16 February 2020).

49. Higgins, S.; Paul, N.T.K. Navigating teacher education reform: Priorities, possibilities and pitfalls. In Sustainable Peacebuilding and Social Justice in Times of Transition; Cardozo, M.T.A.L., Maber, E.J.T., Eds.; Springer: Singapore, 2019; pp. 141-161.

50. Heslop, L. Encountering Internationalisation: Higher Education and Social Justice in Myanmar. Doctoral Thesis, University of Sussex, Brighton, UK, 2019.

51. May San, Y. Presentation on 'Upgrading of Education Colleges to Four-Year Degree Colleges', Higher Education Forum. 2017. Available online: http:/ / www.moe.gov.mm/ (accessed on 9 August 2021)(In Myanmar Language).

52. Connecting Higher Education Institutions for a New Leadership on National Education. In [CHINLONE] (2018). Myanmar's Higher Education Reform: Which Way Forward? University of Bologna: Bologna, Italy, 2018. Available online: https://site.unibo.it/ chinlone/it/report (accessed on 15 October 2021).

53. Welch, A.; Hayden, M.; Myanmar Comprehensive Education Sector Review (CESR) Phase 1: Rapid Assessment. Technical Annex on the Higher Education Subsector. CESR. Myanmar. 2013. Available online: http://www.cesrmm.org/assets/home/img/cesrphase\%201_rapid\%20assessment_higher\%20ed\%20subsector_technical\%20annex_26mar13_for\%20distrib_cln_newlogo.pdf (accessed on 15 October 2021).

54. Kamibeppu, T.; Chao, R.Y., Jr. Higher Education and Myanmar's Economic and Democratic Development. Int. High. Educ. 2017, 88, 19-20. [CrossRef]

55. Ministry of Education. National Education Strategic Plan 2016-2021; Government of Myanmar: Nay Pyi Taw, Myanmar, 2016 Available online: http:/ / www.moe.gov.mm/en/?q=content/national-education-strategic-plan (accessed on 8 August 2021).

56. Hong, M.S.; Chun, Y.J. Symbolic habitus and new aspirations of higher education elites in transitional Myanmar. Asia Pac. Educ. Rev. 2021, 22, 67-76. [CrossRef]

57. Nakanishi, Y. Reconsidering the origin of the contemporary Myanmar politics. JPN J. Southeast Asian Stud. 2019, 56, $240-246$.

58. Human Rights Watch. 2 March 2021. Available online: https://www.hrw.org/node/378044/printable/print (accessed on 8 August 2021).

59. Bhattacharya, S. Institutional review board and international field research in conflict zones. PS Political Sci. Politics 2014, 47, 840-844. [CrossRef]

60. Schulz, P. Recognizing research participants' fluid positionalities in (post-) conflict zones. Qual. Res. 2021, 21, 550-567. [CrossRef]

61. ADB. Learning and earning losses from COVID-19 school closures in developing Asia; Special Topic of the Asian Development Outlook; Asian Development Outlook: Manila, Philippines, 2021.

62. MRTV (2021). Available online: https:/ / www.myanmartvchannels.com/education-channel.html (accessed on 20 January 2021).

63. Asian Network for Free Elections (ANFREL). The 2020 Myanmar General Elections: Democracy Under Attack._ANFREL International Election Observation Mission Report; ANFREL: Bangkok, Thailand, 2021.

64. Annawitt, P. Myanmar's junta is in a much weaker position than many realize Nikkei Asia. 2021. Available online: https: / / asia.nikkei.com/Opinion/Myanmar-s-junta-is-in-a-much-weaker-position-than-many-realize (accessed on 20 February 2021).

65. Channel News Asia (4 March 2021). Available online: https://www.channelnewsasia.com/news/asia/myanmar-coup-activistsvow-more-protests-after-38-killed-14329382 (accessed on 8 July 2021).

66. The Lancet. Myanmar's democracy and health on life support. Lancet 2021, 397, 1035. [CrossRef]

67. Lall, M. Myanmar Higher Education in light of the military coup. Int. High. Educ. 2021, 107, 37-39.

68. BBC News. Myanmar Coup: Teachers Join Growing Protests against Military. 5 February 2021. Available online: https: //www.bbc.com/news/world-asia-55944482 (accessed on 5 February 2021).

69. Naw Say Phaw Waa. 2021. Junta Announces a Return to Classes-But Not Normality. University World News, 23 April. Available online: https: / / www.universityworldnews.com/post.php?story=20210423115051629 (accessed on 9 August 2021).

70. DW. 2021. Myanmar: First Protester Dies in Rallies Against Military Takeover. Available online: https://www.dw.com/en/ myanmar-first-protester-dies-in-rallies-against-military-takeover/a-56622106 (accessed on 9 August 2021).

71. Assistance Association for Political Prisoners (Burma). 2021. Available online: https://aappb.org/ (accessed on 30 September 2021)

72. Aljazeera. 2021. 75 Children Killed, 1,000 Detained Since Myanmar Coup: UN Experts. Available online: https://www.aljazeera. com/news/2021/7/17/75-children-killed-1000-detained-since-myanmar-coup-un-experts (accessed on 9 August 2021).

73. Britannica. 2021. Myanmar: The Emergence of Nationalism. Available online: https://www.britannica.com/place/Myanmar/ The-emergence-of-nationalism (accessed on 10 August 2021). 
74. Cheesman, N. Legitimising the Union of Myanmar through Primary School Textbooks. Master's Thesis, University of Western Australia, Crawley, Australia, 2002. Available online: https:/ / research-repository.uwa.edu.au/en/publications/legitimising-theunion-of-myanmar-through-primary-school-textbook (accessed on 7 February 2020).

75. Metro, R. History Curricula and the Reconciliation of Ethnic Conflict: A Collaborative Project with Burmese Migrants and Refugees in Thailand. Ph.D. Thesis, Cornell University, Ithaca, NY, USA, 2011.

76. Baronio, F. Myanmar's Army Will Do Whatever It Takes to Hold Onto Power. 2021. Available online: https://www.ispionline.it/ en/pubblicazione/myanmars-army-will-do-whatever-it-takes-hold-power-31157 (accessed on 9 August 2021).

77. Mullen, M. On Pathways That Changed Myanmar: A Précis. J. Int. Glob. Stud. 2017, 8, 50-63.

78. Teacircleoxford. Targets of Oppression and Scrutiny: Being a University Teacher in Military-Ruled Myanmar. 2021. Available online: https: / teacircleoxford.com/2021/10/25/targets-of-oppression-and-scrutiny-being-a-university-teacher-in-militaryruled-myanmar (accessed on 15 October 2021).

79. Reuters. 2021. More than 125,000 Myanmar Teachers Suspended for Opposing Coup. Available online: https://www.reuters.com/ world/asia-pacific/more-than-125000-myanmar-teachers-suspended-opposing-coup-2021-05-23/ (accessed on 6 August 2021).

80. Saito, E. Ethical challenges for teacher educators in Myanmar due to the February 2021 coup. Power Educ. 2021, 13, 205-212. [CrossRef]

81. Naw Say Phaw Waa. 2021. Military Re-Opens Universities but Few Students Attend. Available online: https://www. universityworldnews.com/post.php?story=20210506230745241 (accessed on 6 August 2021).

82. Myanmar Now. 2021. Some 90 Percent of Myanmar Students Refuse to Attend School under Coup Regime, Teachers Say. Available online: https:/ / www.myanmar-now.org/en/news/some-90-percent-of-myanmar-students-refuse-to-attend-schoolunder-coup-regime-teachers-say?page $=66 \&$ width $=500 \&$ height $=500 \&$ inline $=$ true (accessed on 8 August 2021).

83. Irrawaddy. 2021. Myanmar Schools Open, But Classrooms Are Empty as Students Boycott. Available online: https://www. irrawaddy.com/news/burma/myanmar-schools-open-but-classrooms-are-empty-as-students-boycott.html (accessed on 8 August 2021)

84. Kostovicova, D.; Knott, E. Harm, change and unpredictability: The ethics of interviews in conflict research. Qual. Res. 2020 [CrossRef]

85. Gill, J.; DeFronzo, J. A Comparative Framework for the Analysis of International Student Movements. Soc. Mov. Stud. 2009, 8, 203-224. [CrossRef]

86. Krieger, Z. 2007. Iraq's Universities near Collapse. Chron. High. Educ. 2007, 53, A35. 